bioRxiv preprint doi: https://doi.org/10.1101/717843; this version posted August 28,2019 . The copyright holder for this preprint (which was not certified by peer review) is the author/funder, who has granted bioRxiv a license to display the preprint in perpetuity. It is made available under aCC-BY-NC-ND 4.0 International license.

\title{
Depression of substantia nigra dopamine transmission is driven by retrograde neurotensin release and is enhanced by methamphetamine self-administration
}

Christopher W. Tschumi ${ }^{1}$, Ramaswamy Sharma², William B. Lynch ${ }^{1}$, Amanda L. Sharpe ${ }^{3}$, Michael J. Beckstead ${ }^{1}$

${ }^{1}$ Aging \& Metabolism Research Program, Oklahoma Medical Research Foundation, Oklahoma City, OK 73104

${ }^{2}$ Department of Cell Systems \& Anatomy, University of Texas Health, San Antonio, TX 78229

${ }^{3}$ College of Pharmacy, University of Oklahoma Health Sciences Center, Oklahoma City, OK 73117

Corresponding author:

Mike Beckstead

Aging \& Metabolism Research Program

Oklahoma Medical Research Foundation

$825 \mathrm{NE} 13^{\text {th }} \mathrm{St}$.

Oklahoma City, OK 73104

(405) 271-7575

Mike-Beckstead@omrf.org

Running title: METH experience enhances neurotensin $L T D_{D A}$ 
bioRxiv preprint doi: https://doi.org/10.1101/717843; this version posted August 28, 2019. The copyright holder for this preprint (which was not certified by peer review) is the author/funder, who has granted bioRxiv a license to display the preprint in perpetuity. It is made available under aCC-BY-NC-ND 4.0 International license.

\section{Abstract}

Midbrain dopamine neurons play central roles in reward learning and motivated behavior, and inhibition at somatodendritic dopamine D2 receptor (D2R) synapses blunts psychostimulant reinforcement. Release of the neuropeptide neurotensin in the midbrain increases following methamphetamine exposure and induces long-term depression of $D 2 R$ synaptic currents ( $\left.L T D_{D A}\right)$, however the source of neurotensin that drives $L T D_{D A}$ is not known. Here we show that $L T D_{D A}$ is driven by neurotensin released by dopamine neurons. Optogenetic stimulation of dopamine neurons was sufficient to induce LTD $_{D A}$ in the substantia nigra, but not the ventral tegmental area, and was dependent on neurotensin receptors, postsynaptic calcium, and vacuolar-type $\mathrm{H}^{+}$-ATPase activity in the postsynaptic cell. Further, LTD $_{\mathrm{DA}}$ was enhanced in mice that had self-administered methamphetamine. These findings reveal a novel form of signaling between dopamine neurons involving release of the peptide neurotensin, which may act as a feed forward mechanism to increase dopamine neuron excitability and methamphetamine self-administration. 


\section{Introduction}

Midbrain dopamine neurons of the substantia nigra pars compacta (SNc) and ventral tegmental area (VTA) play central roles in the initiation of movement and motivated behavior. Thus, a complete understanding of the determinants of dopamine neuron excitability is of critical importance in understanding these complex behaviors. Dopamine neurons inhibit each other through a relatively slow form of dendritic neurotransmission mediated by postsynaptic dopamine D2 autoreceptors (D2Rs, Beckstead et al; 2004; Robinson et al., 2017). Dendritic dopamine neurotransmission can be measured in mouse brain slices by electrically evoking dopamine release and electrophysiologically recording the subsequent D2R-, potassium channel-mediated inhibitory postsynaptic currents (D2IPSCs, Beckstead et al., 2004). Previous work from our lab shows that D2-IPSCs undergo long-term depression (LTD DA) subsequent to low-frequency electrical stimulation (Beckstead and Williams, 2007; Piccart et al., 2015) through a mechanism likely involving signaling by the neuropeptide neurotensin (NT, Piccart et al., 2015).

NT is expressed throughout the central nervous system, and in both the midbrain and striatum (a major dopamine projection region) it can affect dopamine-mediated behaviors including food- and psychostimulant- reinforced responding (Dominguez-Lopez et al., 2018; Kempadoo et al., 2013; Leinninger et al., 2011; Patterson et al., 2015; Tschumi and Beckstead, 2018; Tschumi and Beckstead, 2019). Conversely, exposure to abused drugs including morphine, cocaine, and methamphetamine can induce NT peptide upregulation or release across different brain regions (Betancur et al., 2001; Frankel et al., 2011; Geisler and Zahm, 2006; Hanson et al., 2013; Stiller et al., 1997; Tschumi and Beckstead, 2019). Incredibly, exogenous NT application induces synaptic plasticity of GABAergic, dopaminergic, and glutamatergic input to dopamine neurons, as well as activating cell-autonomous endocannabinoid signaling in those cells (Kortleven et al., 2012; Kempadoo et al., 2013; Bose et al., 2015; Stuhrman and Roseberry, 2015; Piccart et al., 2015; Gantz and Bean, 2017; Tschumi and Beckstead, 2018; Tschumi and Beckstead, 2019). NT release from lateral hypothalamic inputs to the VTA drives plasticity at glutamatergic synapses (Kempadoo et al., 2013), but the endogenous source of NT which drives plasticity at dendrodendritic dopamine synapses is not known. Therefore, physiological delineation of NT signaling is central to understanding synaptic plasticity in, and excitability of, dopamine neurons.

Here we show that $L T D_{D A}$ in the SNc is driven by neurotensin release from dopamine neurons. We used transgenic and viral targeting to enable optogenetic stimulation of dopamine neurons or NT terminals projecting from either the lateral hypothalamus (LH) or nucleus accumbens (NAc) to the VTA. Targeted stimulation of dopamine neurons drove LTD $_{D A}$ in the SNc that was prevented by neurotensin receptor antagonism, as well as postsynaptic chelation of calcium or inhibition of vacuolar-type $\mathrm{H}^{+}$-ATPase (V-ATPase). LTDDA was also enhanced in mice that self-administer methamphetamine, however, neither stimulation of dopaminergic, lateral hypothalamic, or accumbal NT-expressing inputs were sufficient to drive $L T D_{D A}$ in the VTA. These findings provide evidence for a second form of inter-dopamine neuron signaling which proceeds through local NT release, and indicates that this form of communication may be dysregulated as a result of methamphetamine use. 


\section{Results}

\section{Repetitive stimulation of dopamine neurons is sufficient to drive $L T D_{D A}$ in the SNc}

We previously found that stimulation-induced long-term depression of D2-IPSCS (LTD DA, Beckstead and Williams, 2007) is driven by endogenous NT signaling (Piccart et al., 2015) and suggested that dopamine neurons might also release NT. Thus, to determine the source of NT which drives LTD $_{\mathrm{DA}}$ we used a combination of transgenic and optogenetic tools to delineate the role of dopamine neurons and NT afferents to the midbrain. We first generated a mouse expressing channelrhodopsin (ChR2) specifically in dopamine neurons by cross-breeding dopamine transporter (DAT)-Cre and cre-dependent ChR2 mouse lines (Figure $1 \mathrm{A1}-3, \mathrm{~B})$. Using whole-cell voltage clamp (-55 mV) recordings of SNc dopamine neurons, we determined that blue light optical stimulation, like electrical stimulation (Beckstead et al., 2004), generated slow outward synaptic currents that were blocked by the dopamine D2 receptor antagonist sulpiride (D2-olPSCs, Figure 1 C1-2) or by the voltage-gated sodium channel blocker tetrodotoxin (Figure $1 \mathrm{D}$ ), and were dependent on the presence of extracellular $\mathrm{Ca}^{2+}$ (Figure $1 \mathrm{E}$ ). This suggests that optogenetic excitation of dopamine neurons and subsequent dopamine release closely resembles physiological dopamine neurotransmission (Beckstead et al., 2004). Furthermore, acute bath application of methamphetamine increased both D2-olPSC amplitude and width, suggesting that the kinetics of the synaptic current are tightly regulated by dopamine uptake (Figure 1 F1-3). Thus, optogenetic stimulation allows for an assessment of dopamine neuron excitation without stimulation of other cell types and without including blockers of other neurotransmitter receptors, and revealed that repeated optostimulation of dopamine neurons $(10 \mathrm{~Hz}, 2 \mathrm{~min})$ is sufficient to drive $\operatorname{LTD}_{\mathrm{DA}}\left(\mathrm{t}_{5}=5.04, \mathrm{p}=0.0040\right.$; Figure $\left.1 \mathrm{G1}-3\right)$.

\section{$\mathrm{LTD}_{\mathrm{DA}}$ requires NT type-2 receptor signaling, and postsynaptic calcium and V-ATPase}

As dopamine neurons express both type 1 and 2 NT receptors (Sarret et al., 1998; Mazella et al., 1988), we next investigated if optostimulation-induced LTD $D_{D A}$ is dependent on NT signaling. Pre-incubation with the non-selective NT type 1/2 receptor antagonist SR 142948 prevented LTD DA (Figure 2 A 1-2, F; one-way ANOVA, $F_{4,26}=18.92, p<0.0001$, Tukey's, $p=0.0001$ ). Conversely and consistent with our previous findings (Piccart et al., 2015), a selective NT type-1 receptor antagonist failed to prevent $L_{T D}$ (Figure 2 B 1-2, F; $p=0.99$ ). As presumably only dopamine neurons are being depolarized by the blue light, this suggests that dopamine neurons are themselves releasing NT that induces LTD $D_{D A}$ though activation of NT type-2 receptors. Furthermore, buffering calcium by dialyzing the postsynaptic cell with BAPTA

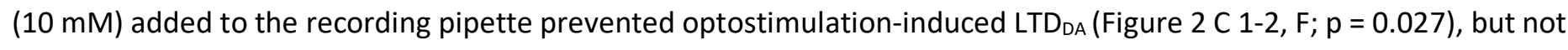

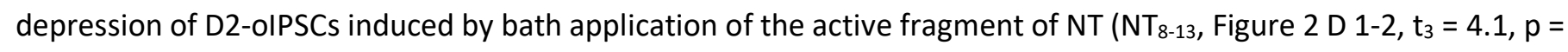
0.026). Together, these findings suggest that NT-induced depression of D2-olPSCs is not dependent on intracellular calcium per se, as NT perfusion may bypass a postsynaptic calcium-dependent step in stimulation-induced LTD DA.

NT-induced synaptic plasticity in other brain regions is dependent on dopamine D1 receptor (D1R) signaling (Krawczyk et al., 2013), and an alternative explanation is that D1R-expressing axon terminals in the midbrain (Levey et 
bioRxiv preprint doi: https://doi.org/10.1101/717843; this version posted August 28, 2019. The copyright holder for this preprint (which was not certified by peer review) is the author/funder, who has granted bioRxiv a license to display the preprint in perpetuity. It is made available under aCC-BY-NC-ND 4.0 International license.

al., 1993) could produce NT release subsequent to optostimulation of dopamine neurons. However, the selective D1R antagonist SKF $38393\left(10 \mu \mathrm{M}\right.$ ) failed to prevent $\operatorname{LTD}_{\mathrm{DA}}$ (Figure $\mathrm{S} 1 \mathrm{~A}, \mathrm{~B} ; \mathrm{t}_{4}=5.5, \mathrm{p}=0.0054$ ). As calcium chelation prevents optostimulation-induced $L T D_{D A}$, and NT is released from dopamine neurons in a calcium-dependent manner (Kitabgi et al., 1990), we next investigated if the dopamine neuron being recorded releases NT to drive $L T D_{D A}$ in a cell-autonomous manner. NT is found in dense-core vesicles in dopamine neuron dendrites (Bayer et al., 1991), release of which should be inhibited by V-ATPase, which is necessary for both proper trafficking of neuropeptide-containing dense core vesicles (Taupenot et al., 2005) and NT release in other brain regions (Krawczyk et al., 2013, Normandeau et al., 2017). Indeed,

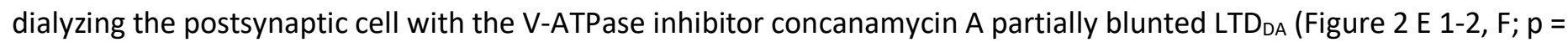
0.005). While these experiments do not definitively exclude the release of other signaling molecules, these results suggest that NT is released in a calcium- and V-ATPase-dependent manner from dopamine neurons located postsynaptic to other dopamine neurons.

\section{Repetitive stimulation of dopamine neurons or other NT inputs is not sufficient to drive LTD $_{D A}$ in the VTA}

As NT peptide has been observed in cell bodies and terminals in both the SNc and VTA, we next examined if dopamine neuron stimulation is sufficient to drive LTD $_{\mathrm{DA}}$ in VTA dopamine neurons. Although we have previously shown that bath perfusion of NT induces depression of D2R signaling in VTA dopamine neurons (Piccart et al., 2015), optostimulation surprisingly failed to induce $L_{T D}$ in most of the VTA neurons recorded (Figure 3 A $1-3 ; t_{4}=0.75, p=$ 0.50), suggesting the presence of brain region-specific interactions between NT and dopamine transmission. However, consistent with previous findings (Beckstead and Williams, 2007), electrical stimulation did induce LTD $D_{D A}$ in the VTA (Figure S2 A, B). The fact that optostimulation-induced LTD DA is NT-dependent combined with previous findings that bath-perfused NT depresses D2-IPSCs (Piccart et al., 2015) suggests that electrical stimulation may elicit NT release from non-dopamine cells to induce $L T D_{D A}$ in VTA dopamine neurons.

We next investigated two prominent NT-expressing inputs to the VTA: 1) the LH afferents to the VTA, which have only weak projection to the SNc (Patterson et al., 2015), and 2) the NAc inputs to the VTA, which express increased levels of NT following methamphetamine exposure (Geisler and Zahm, 2006). NT, like many neuropeptides, is coexpressed in neurons that form synaptic connections and generate either GABA- or glutamate-mediated postsynaptic currents in VTA dopamine neurons (Leinninger et al., 2013; Kempadoo et al., 2013; Tschumi and Beckstead, 2019). In order to specifically stimulate these inputs, NTS-Cre mice that express Cre-recombinase specifically in cells that express NT were administered bilateral intra-LH or intra-NAc injections of AAV to drive cre-inducible expression of ChR2 (schematic; Figure 3 B1, 4 A1). Both immunohistochemistry (Figure 3 B2) and live-slice imaging (observed during recordings, data not shown) revealed terminals from NT-expressing LH inputs to the VTA, and optostimulation of these inputs generated fast postsynaptic currents in a fraction of both dopamine and non-dopamine neurons recorded (Figure 3 C1-2). However, recordings of D2-IPSCs in a separate group of cells revealed no induction of LTD DA by targeted stimulation of NT-expressing LH inputs to the VTA (Figure 3 D1-3; $t_{3}=0.80, p=0.48$ ). Similarly, optogenetic stimulation 
of NT-expressing NAc inputs to the VTA (Figure 4 A1-2) generated postsynaptic currents in only a fraction of cells recorded (Figure 4 B1-2) and failed to induce $L_{T D}$ (Figure 4 C1-3; $t_{7}=0.223, p=0.87$ ). Together, these results suggest that unlike in the SNc, LTD arising from the NAC and $\mathrm{LH}$.

\section{LTD $_{\mathrm{DA}}$ is enhanced in mice that self-administer methamphetamine}

Midbrain dopamine signaling is perturbed presynaptically at the level of spontaneous dopamine release and postsynaptically at D2Rs following in vivo psychostimulant exposure (Gantz et al., 2015, Sharpe et al., 2014). To determine if dendrodendritic dopamine neurotransmission and plasticity are affected by repeated psychostimulant exposure, we measured D2-eIPSCs from mice that had a history of operant self-administration of methamphetamine. Following recovery from jugular catheter implantation surgery, mice were placed in an operant chamber for selfadministration of methamphetamine ( 2 hours/day). Each operant chamber was equipped with 2 nose-poke holes, and responding in one hole resulted in an infusion of methamphetamine $(0.1 \mathrm{mg} / \mathrm{kg})$ while responding in the inactive hole had no consequence. Initially, mice were trained to self-administer methamphetamine on a schedule of reinforcement that progressed within-session from fixed ratio 1 (each response results in an infusion, FR1) to fixed ratio 3 (FR3). After mice acquired stable responding with high accuracy in the active hole $(89.5 \pm 4.0 \%)$ they were transitioned to an FR3 schedule of reinforcement for a minimum of nine days. Mice self-administered $2.38 \pm 0.10 \mathrm{mg} / \mathrm{kg} / \mathrm{day}$ and continued to respond with a high degree of accuracy ( $91 \pm 1.0 \%$ nose-pokes in active nose-poke hole) in the 5 sessions preceding electrophysiological recordings (Figure 5 A1-2). In recordings from SNc dopamine neurons in the presence of a cocktail of antagonists to block acetylcholine, GABA, and glutamate signaling, repetitive electrical stimulation (10 Hz, $2 \mathrm{~min})$ induced $L T D_{D A}$ in both groups (Figure 5 B1, B3; naïve, $t_{4}=4.86, p=0.008$; methamphetamine, $t_{6}=4.58, p=0.004$ ), however the effect was larger in neurons from mice that self-administered methamphetamine (Figure 5 B2; $\mathrm{t}_{10}=2.34, \mathrm{p}$ $=0.041)$. In agreement with previous studies from our lab showing that methamphetamine self-administration decreases D2R currents (Sharpe et al., 2014), D2-elPSCs were of smaller amplitude in mice that self-administered methamphetamine compared to drug-naïve controls (Figure 5 B3; Naïve vs. METH; $t_{10}=3.10, p=0.011$ ). Together, these results suggest that although methamphetamine-self administration decreases dendritic dopamine transmission, the ability to induce $L T D_{D A}$ persists and is actually enhanced.

\section{Discussion}

\section{NT release by dopamine neurons}

Our data show that selective optostimulation of dopamine neurons is sufficient to evoke D2 receptor-mediated inhibitory synaptic transmission in these cells, and in the SNc repeated activation of dopamine neurons is sufficient to induce plasticity of that response. This finding is consistent with NT acting as a retrograde transmitter at dendrodendritic 
synapses between dopamine neurons in the SNc. NT-dependent communication between dopamine neurons meets the criteria of retrograde transmitter release put forth by Regehr and colleagues (2009): NT is present in the postsynaptic cell (Seroogy et al., 1988), disruption of release from the postsynaptic cell prevents signaling, and NT receptors are located presynaptically (Sarret et al., 1998; Tanaka et al., 1990). Further, while local, polysynaptic mechanisms of action are difficult to completely rule out, the lack of effect of antagonizing $\mathrm{G}_{\mathrm{s}}$-coupled $\mathrm{D} 1$ receptors is strong evidence against such a process. Here we show that NT-dependent LTD DA can be inhibited either by 1) blockade of NT receptors, or 2) disruption of NT release through either chelation of calcium or inhibition of V-ATPase. We have previously shown that exposing the presynaptic dopamine neuron to NT by bath application decreases dopamine release (Piccart et al., 2015). Currently available tools do not allow for cell-targeted disruption of NT release from dopamine neurons. NT is not synthesized by dopamine neurons, but enters via sequestration through the high-affinity NT receptor (Castel et al., 1990; Laduron, 1995). Therefore, while somewhat limited by peculiarities of NT physiology, the findings presented here provide strong evidence that NT is released from postsynaptic dopamine neurons and acts as a retrograde messenger to decrease dopamine release presynaptically.

Dopamine neurons also release endocannabinoids which act as retrograde messengers at both GABA and glutamate inputs, or as autocrine signals (Covey et al., 2017). However, a lack of CB-1 endocannabinoid receptors on dopamine neurons suggests that endocannabinoids do not act as retrograde messengers at dendrodendritic dopamine synapses (Julian et al., 2003). Notably, NT signaling via NT type-1 receptors mobilizes endocannabinoid-induced depression of glutamatergic inputs to dopamine neurons (Kortleven et al., 2012). Thus, NT release by dopamine neurons may also induce endocannabinoid release from neighboring dopamine neurons. Taken together, our findings suggest that NT release may act as a dopamine neuron-driven feedback which results in both depression of local dopamine signaling and endocannabinoid-induced plasticity that alters the balance of excitatory and inhibitory inputs to dopamine neurons.

\section{Dendritic dopamine transmission and methamphetamine self-administration}

NT-induced depression of D2 signaling could have a significant impact on reward-related behavior. Burst firing of dopamine neurons, canonically generated by unexpected rewards (Schultz, 1998), strongly drives inhibitory dendrodendritic dopamine signaling and is critical for reward-driven behavior (Beckstead et al., 2004, Zweifel et al., 2009). Dendrodendritic D2 signaling occurs at a timescale that is ideal to terminate burst-firing (Beckstead et al., 2004) and could enhance the specificity of phasic dopamine release. Here we show that D2 current amplitudes in dopamine neurons are reduced by self-administration of the psychostimulant methamphetamine. This could enhance aberrant seeking behavior by circumventing normal inhibitory feedback, blunting the spatial and temporal constraints in dopamine release that typically accompany the presentation of unexpected rewards. Indeed, transgenic mice lacking functional D2Rs show enhanced measures of sensitivity to the rewarding effects of psychostimulants including conditioned place preference, responding on a progressive ratio, acquisition of self-administration, and responding to psychostimulant-paired cues (Bello et al., 2011; de Jong et al., 2015; Holroyd et al., 2015; McCall et al., 2017). 
Several forms of synaptic plasticity have previously been described in dopamine neurons following exposure to psychostimulants. Acting through distinct mechanisms, in vivo exposure to cocaine, morphine, and nicotine all induce long-term potentiation of glutamate signaling in dopamine neurons (Brown et al., 2010). Non-contingent cocaine administration causes long-term potentiation of excitatory glutamate signaling (Ungless et al., 2001; Saal et al., 2003; Bellone and Lüscher, 2006) and dysregulation of inhibitory GABA signaling (Liu et al., 2005; Bocklisch et al., 2013), which is thought to increase both the excitability of dopamine neurons and behavioral effects of psychostimulants. The present findings add to this literature by demonstrating that stimulation-induced depression of D2-mediated currents is enhanced by methamphetamine self-administration. This is consistent with previous reports of 2-to-3-fold higher NT levels in the SNc and dorsal striatum following methamphetamine self-administration (Frankel et al., 2011; Hanson et al., 2013). Furthermore, we have shown that blockade or ablation of NT receptors decreases methamphetamine selfadministration (Dominguez-Lopez et al., 2018; Dominguez-Lopez et al., 2019). Taken together, this suggests that methamphetamine use enhances NT-induced $L T D_{D A}$, disinhibiting dopamine neurons and driving a further increase in reinforcing effects of the drug.

\section{NT in the VTA}

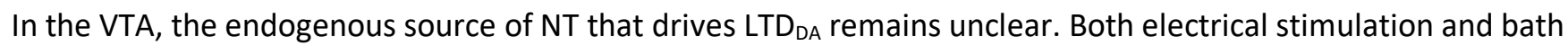
application of NT depress D2-IPSCs in the VTA (Piccart et al., 2015; Stuhrman and Roseberry, 2015). One possibility is that the difference in NT release between SNc and VTA dopamine neurons is due to calcium signaling. NT release in other brain regions is calcium-dependent (Iversen et al., 1978; Kitabgi et al., 1990) and there are substantial differences in calcium binding proteins and ion channel activation in SNc and VTA dopamine neurons (Wolfart et al., 2001, Neuhoff et al., 2002; Rogers, 1992; Liang et al., 1996).

Here we show that NT inputs from both the NAc and the LH to the VTA form synaptic connections with VTA neurons, but generate post synaptic currents in only a small fraction of the neurons recorded and fail to drive $L T D_{D A}$. In agreement with findings reported here of minimal fast-transmitter release from LH and NAc NT-inputs, only 10\% of NT expressing terminals form synaptic contacts with dopamine neurons in the VTA (Woulfe and Beaudet, 1992). Furthermore, targeted activation of LH NT-inputs to the VTA increases NT peptide levels but does not increase glutamate or GABA levels when measured by microdialysis (Patterson et al., 2015). To our knowledge this is the first report of NT NAc-inputs forming functional synaptic connections with dopamine neurons. Altogether, it remains to be determined if NT input originating from a single brain region to the VTA drives NT-induced LTD $_{D A}$, and the degree to which upregulation of NT leads to NT release which in turn drives $L T D_{D A}$.

In summary, our findings show that methamphetamine self-administration enhances TTD $_{D A}$ in the SNC, a form of synaptic plasticity that is driven by dopamine neuron activation and subsequent NT release. The long-lasting decrease in 
bioRxiv preprint doi: https://doi.org/10.1101/717843; this version posted August 28, 2019. The copyright holder for this preprint (which was not certified by peer review) is the author/funder, who has granted bioRxiv a license to display the preprint in perpetuity. It is made available under aCC-BY-NC-ND 4.0 International license.

dendritic dopamine neurotransmission likely enhances excitability of dopamine neurons and may act as a feed forward mechanism to escalate methamphetamine self-administration behavior.

\section{Acknowledgements}

We would like to thank Dr. Gina Leinninger for providing the NTSIREScre mice and for comments on the manuscript.

We would also like to thank Dr. Stephanie Gantz for comments on the manuscript. This work was supported by National Institutes of Health Grants R01 DA032701 (M.J.B), R01 AG052606 (M.J.B.), the John and Mildred Carlson PhD Scholarship Fund (C.W.T.), and funds from the Presbyterian Health Foundation and the Oklahoma Center for Adult Stem Cell Research, a program of TSET. The authors declare no competing financial interests.

\section{Competing interests}

The authors report no relevant competing interests. 
Figure 1. Stimulation of dopamine neurons is sufficient to evoke D2-IPSCs and drive LTD $_{\mathrm{DA}}$ in the SNc. Images depicting tyrosine hydroxylase (TH) (A1), eYFP-fused to ChR2 (A2), and co-localization (A3), scale bar $=20 \mu \mathrm{m}$. Schematic depicting dopamine (DA) neurons from DAT-Cre mice (DAT::Cre) crossed with Ai32 (Cre::ChR2) mice resulting in dopamine neuron-specific expression of eYFP-fused to ChR2 and stimulation by blue light in the SNc (470 nm, B). A blue-light elicited D2-oIPSC during baseline and following bath perfusion of sulpiride (C1), and time-course (C2). Time-courses depicting reduction of D2-oIPSC amplitude during bath perfusion of TTX (D) and calcium-free aCSF (E). Effects of methamphetamine (METH) on D2-oIPSCs (during the peak-effect of METH on amplitude, and later when the effect of METH on half-width was more pronounced, F1), time-course of effect on amplitude (F2), and half-width (F3). Effect of dopamine-neuron specific stimulation (o-stim, $10 \mathrm{~Hz}$ blue light for $2 \mathrm{~min}$ ) on D2-olPSCs (G1), time-course (G2), and raw amplitudes (G3) during an average of 5 baseline sweeps (Pre) and the 5 sweeps 19-23 minutes following optostimulation (Post). ${ }^{* *} p<0.01$

A1

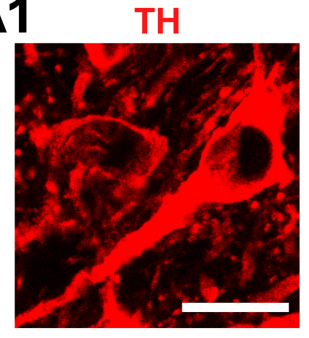

C1
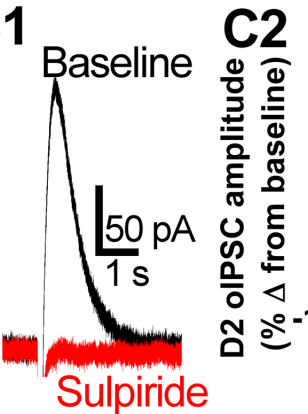

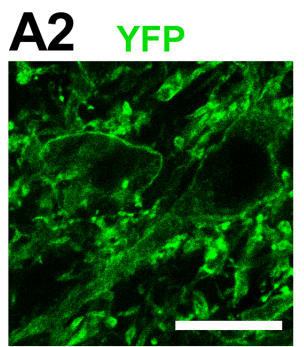

C2

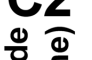

Sulpiride (200 nM)

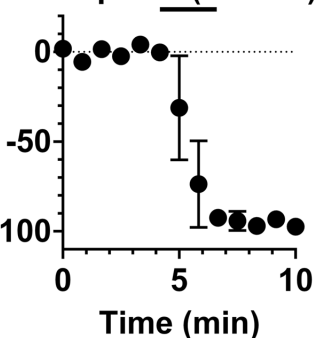

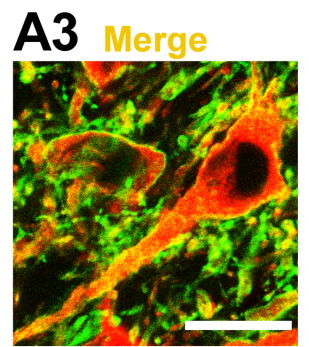
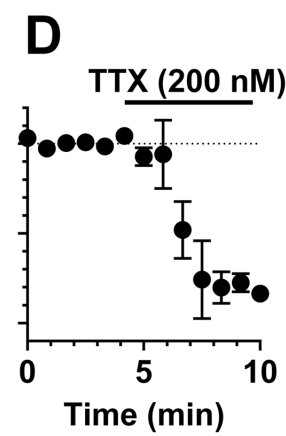

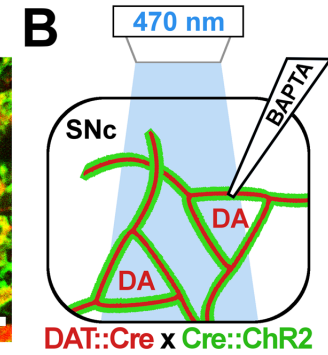

E

$\mathrm{Ca}^{2+}$-free aCSF

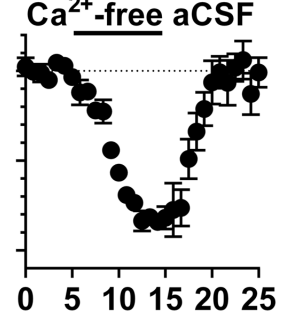

Time (min)

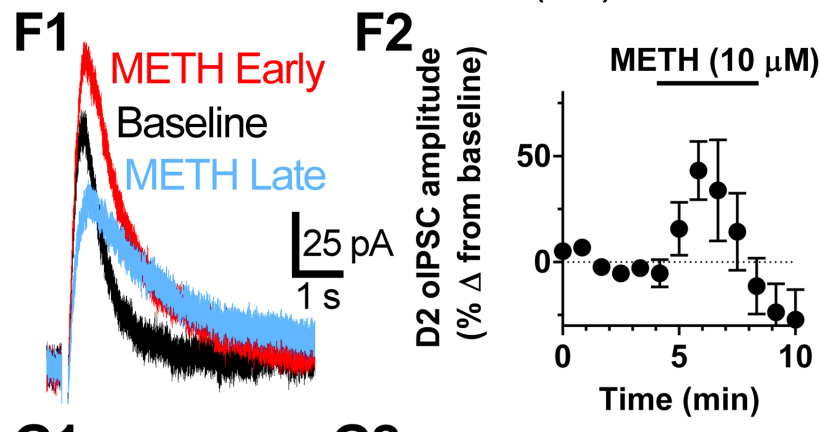

G1

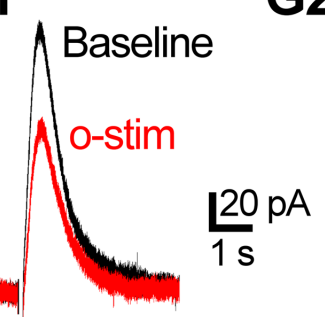

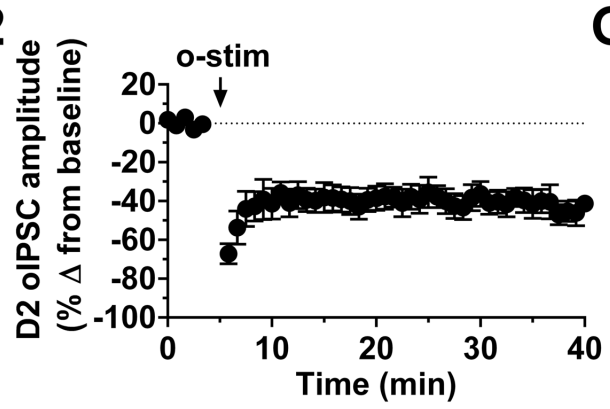

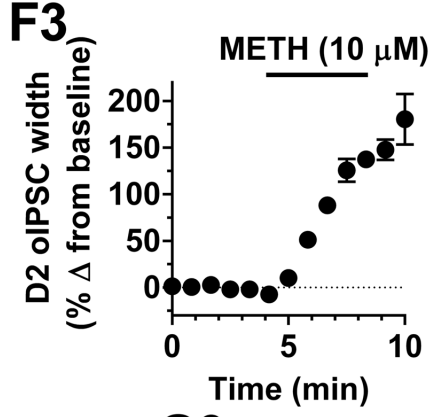

G3

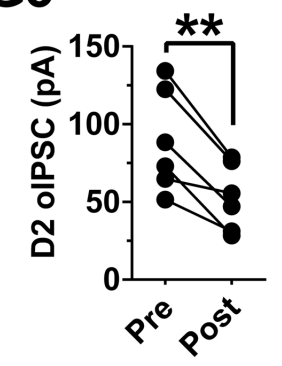


Figure 2. $L T D_{D A}$ requires NT type-2 receptor signaling, plus postsynaptic calcium and V-ATPase. Effect of dopamine neuron-specific stimulation (o-stim, $10 \mathrm{~Hz}$ blue light for $2 \mathrm{~min}$ ) on D2-olPSCs in aCSF (control, grey circles, data first shown in Figure 1) or in the presence of: the non-selective NT type-1/2 receptor antagonist SR142948 (1 $\mu$ M, SR 14, blue hexagons), time-course (A1) and raw amplitudes (A2); the NT type-1 receptor antagonist SR48692 (green diamonds, B1, B2); or with BAPTA (10 mM) added to the recording pipette internal solution (red squares, C1, C2). The effect of 5minute bath perfusion of $\mathrm{NT}_{8-13}$ on D2-olPSCs with BAPTA $(10 \mathrm{mM})$ in the recording pipette $(\mathrm{D} 1, \mathrm{D} 2)$. Effect of optostimulation on D2-olPSCs with concanamycin A (5 $\mu \mathrm{M})$ in the recording pipette (E1, E2). Comparison of percent change from baseline amplitude of D2-olPSCs following optostimulation between groups (F). All raw amplitudes and percent changes are the average of 5 baseline sweeps (Pre) and the 5 sweeps 19-23 minutes following optostimulation (Post). Arrowhead notates optostimulation of dopamine neurons $(10 \mathrm{~Hz}, 2 \mathrm{~min}){ }^{*} \mathrm{p}<0.05, * * p<0.01, * * * p<0.001$

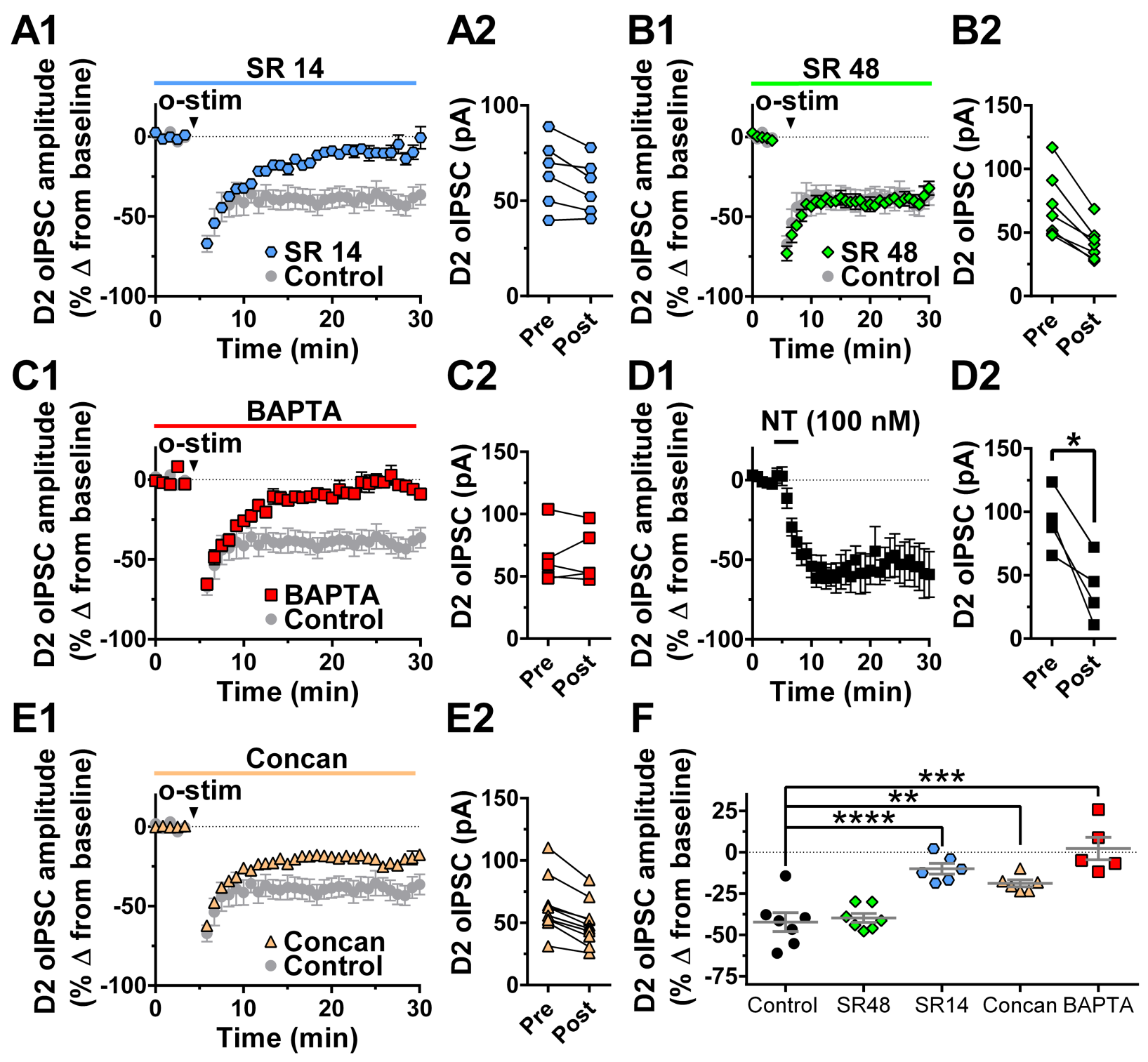


Figure 3. Stimulation of dopamine neurons or NT-expressing inputs from the LH to the VTA does not drive LTD $_{D A}$.

Schematic depicting dopamine (DA) neurons from DAT-Cre mice (DAT::Cre) crossed with Ai32 (Cre::ChR2) mice resulting in dopamine neuron-specific expression of eYFP-fused to ChR2 and stimulation by blue light in the VTA (470 nm, A1). Effect of dopamine-neuron specific stimulation (o-stim, $10 \mathrm{~Hz}$ blue light for $2 \mathrm{~min}$ ) on D2-olPSCs recorded from SNc (SNc, grey circles, data first shown in Figure 1) or VTA dopamine neurons (VTA, black squares), time-course (A2) and raw amplitudes (A3). Schematic depicting NT-expressing neurons in NTS-Cre mice following intra-LH injection of an AAV that drives cre-inducible expression of eYFP-fused to ChR2 (AAV-DIO-ChR2). These inputs were stimulated either by single pulses of blue light $(10 \mathrm{~ms}, 470 \mathrm{~nm})$ or repeated blue-light stimulation $(10 \mathrm{~Hz}, 2 \mathrm{~min}, 5 \mathrm{~ms}$ pulses) to drive NT release (B1). Electrical stimulation (with GABA and glutamate antagonists in the aCSF) was used to elicit D2-elPSCs. Sample image depicting expression of eYFP-fused ChR2 (YFP) near tyrosine-hydroxylase (TH) containing neurons (B2, scale bar = $20 \mu \mathrm{m}$ ). Sample trace of a postsynaptic current (PSC) generated by LH-NT input stimulation (C1, blue bar = $10 \mathrm{~ms}$ bluelight pulse). Chart depicting the percent of dopamine (DA) and non-dopamine neurons (non-DA) in which a PSC was or was not (no PSC) elicited by single-pulse stimulation ( $N=38, C 2$ ). Effect of repeated stimulation of LH NT input to VTA (ostim, $10 \mathrm{~Hz}$ blue light for $2 \mathrm{~min}$ ) on D2-eIPSCs, sample trace (D1), time-course (D2), and raw amplitudes (D3). Raw amplitudes are the average 5 baseline sweeps (Pre) and 5 sweeps 19-23 minutes following optostimulation (Post). 

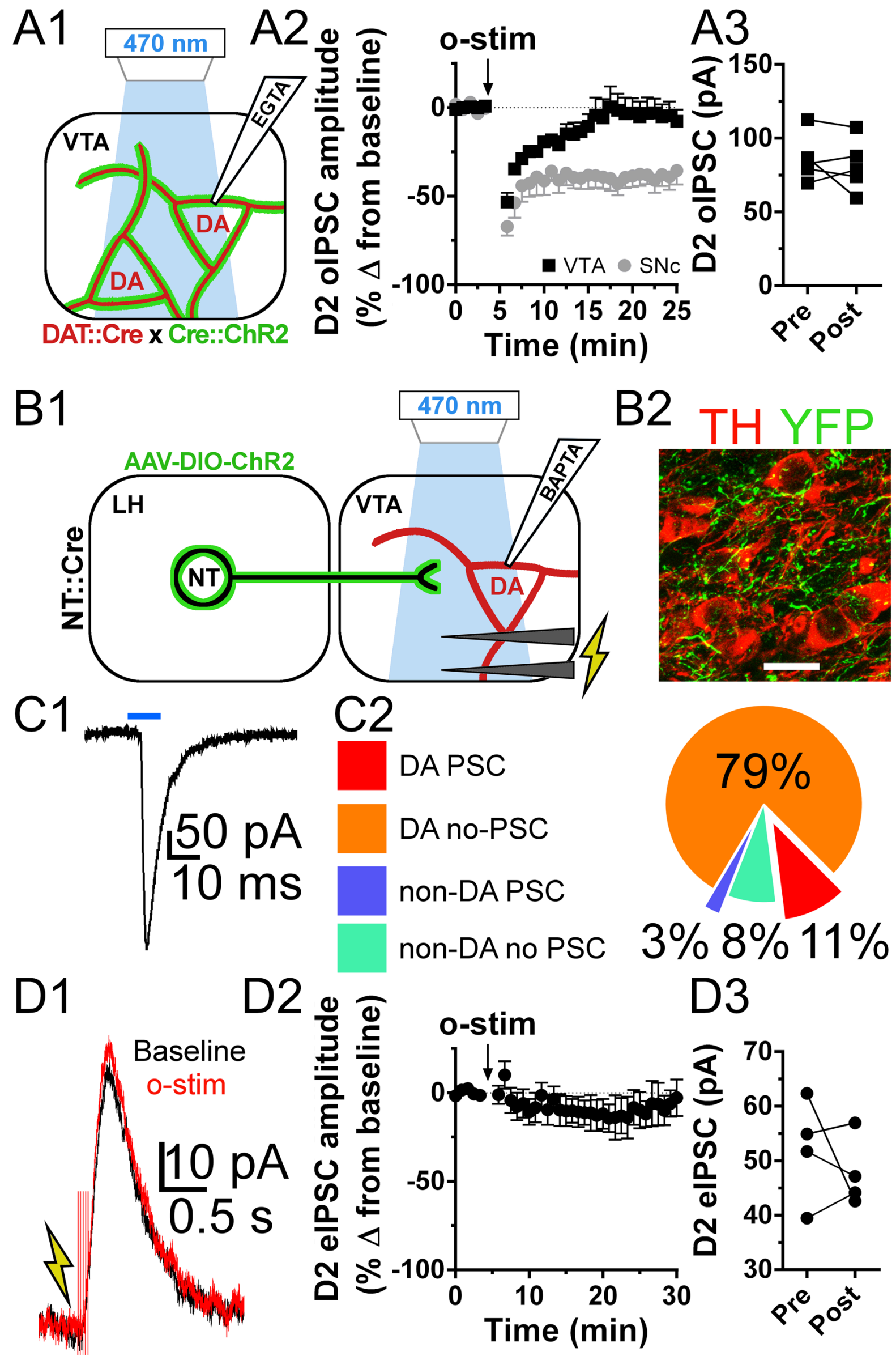
Figure 4. NT-expressing inputs from the NAC to the VTA do not drive LTD $_{\mathrm{DA}}$. Schematic depicting NT-expressing neurons in NTS-Cre mice following intra-NAc infusion of an AAV that drives cre-inducible expression of eYFP-fused to ChR2 (AAVDIO-ChR2). These inputs were stimulated either by single pulses of blue light (10 ms, $470 \mathrm{~nm}$ ) or repeated blue-light stimulation (10 Hz, 2 min, 5 ms pulses) to drive NT release (A1). Electrical stimulation (with GABA and glutamate antagonists in aCSF) was used to elicit D2-eIPSCs. Sample image depicting expression of eYFP-fused ChR2 (YFP) near tyrosine-hydroxylase $(\mathrm{TH})$ containing neurons $(\mathrm{A} 2$, scale bar $=20 \mu \mathrm{m})$. Sample trace of a postsynaptic current (PSC) generated by LH-NT input stimulation (B1, blue bar = $10 \mathrm{~ms}$ blue-light pulse). Chart depicting the percent of dopamine (DA) and non-dopamine neurons (non-DA) in which a PSC was or was not (no PSC) elicited by single-pulse stimulation (N $=15$, B2). Effect of repeated stimulation of NAc NT input to VTA (o-stim, $10 \mathrm{~Hz}$ blue light for $2 \mathrm{~min}$ ) on D2-elPSCs, sample trace (C1), time-course (C2), and raw amplitudes (C3). Raw amplitudes are the average 5 baseline sweeps (Pre) and 5 sweeps 19-23 minutes following optostimulation (Post).

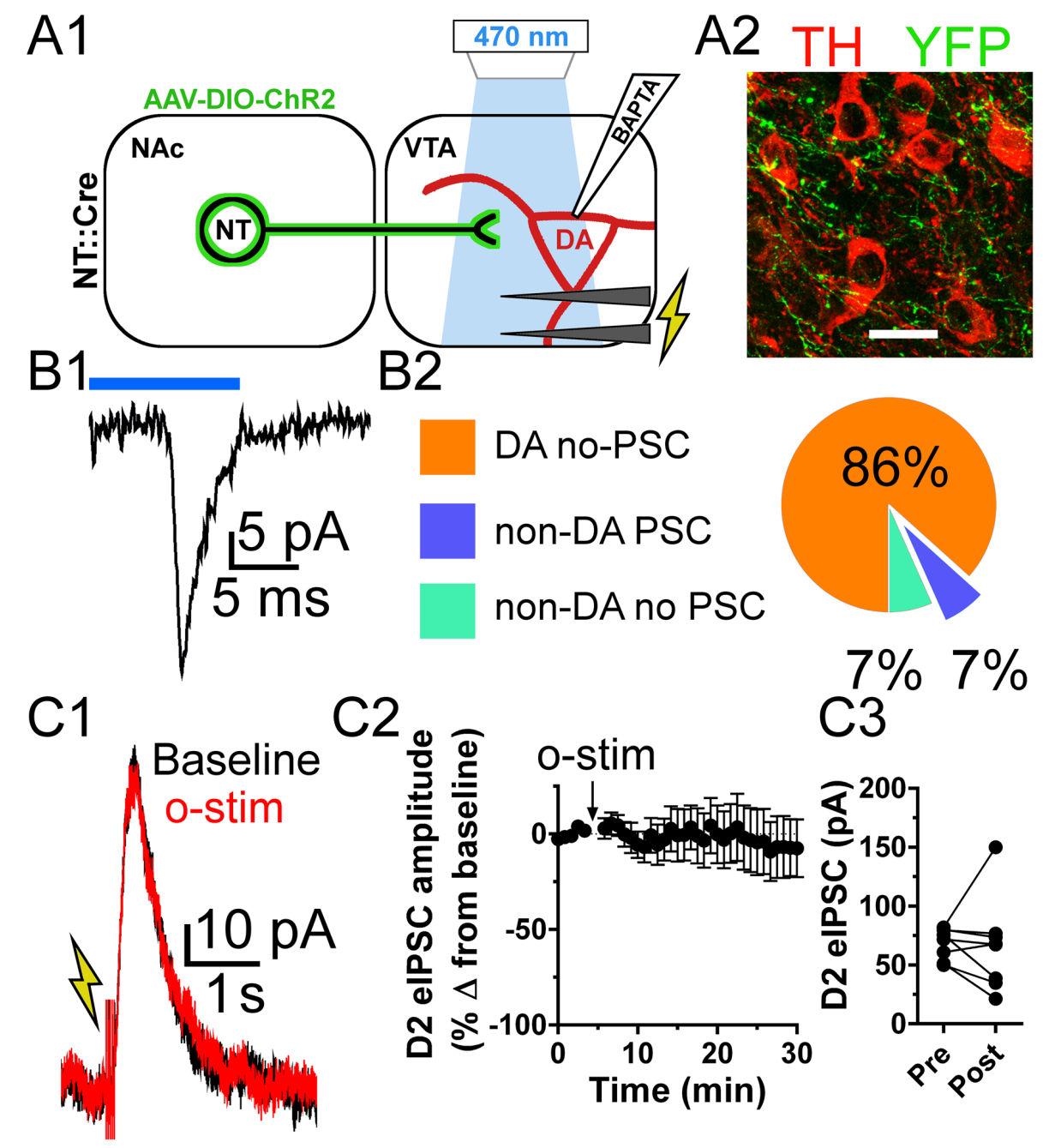


Figure 5. $L T D_{D A}$ is enhanced in mice that previously self-administered methamphetamine. Mice performed methamphetamine (METH) self-administration (i.v.) during daily training sessions (FR1 $\rightarrow$ FR3 schedule), followed by daily maintenance sessions (FR3); average METH intake during each session (A1), and average responding in correct and incorrect nose-poke holes (A2). Effect of electrical stimulation (e-stim, $10 \mathrm{~Hz}$ stimulation for $2 \mathrm{~min}$ ) on D2-elPSCs recorded from SNc dopamine neurons of mice that self-administered METH (Red triangles) and drug naïve controls (Ctrl, black circles); time-course (B1), average change from baseline (B2), and raw amplitudes (B3). Raw amplitudes are the average of 5 baseline sweeps (Pre) and the 5 sweeps $19-23$ minutes following e-stim (Post). ${ }^{*} p<0.05,{ }^{*} p<0.01$
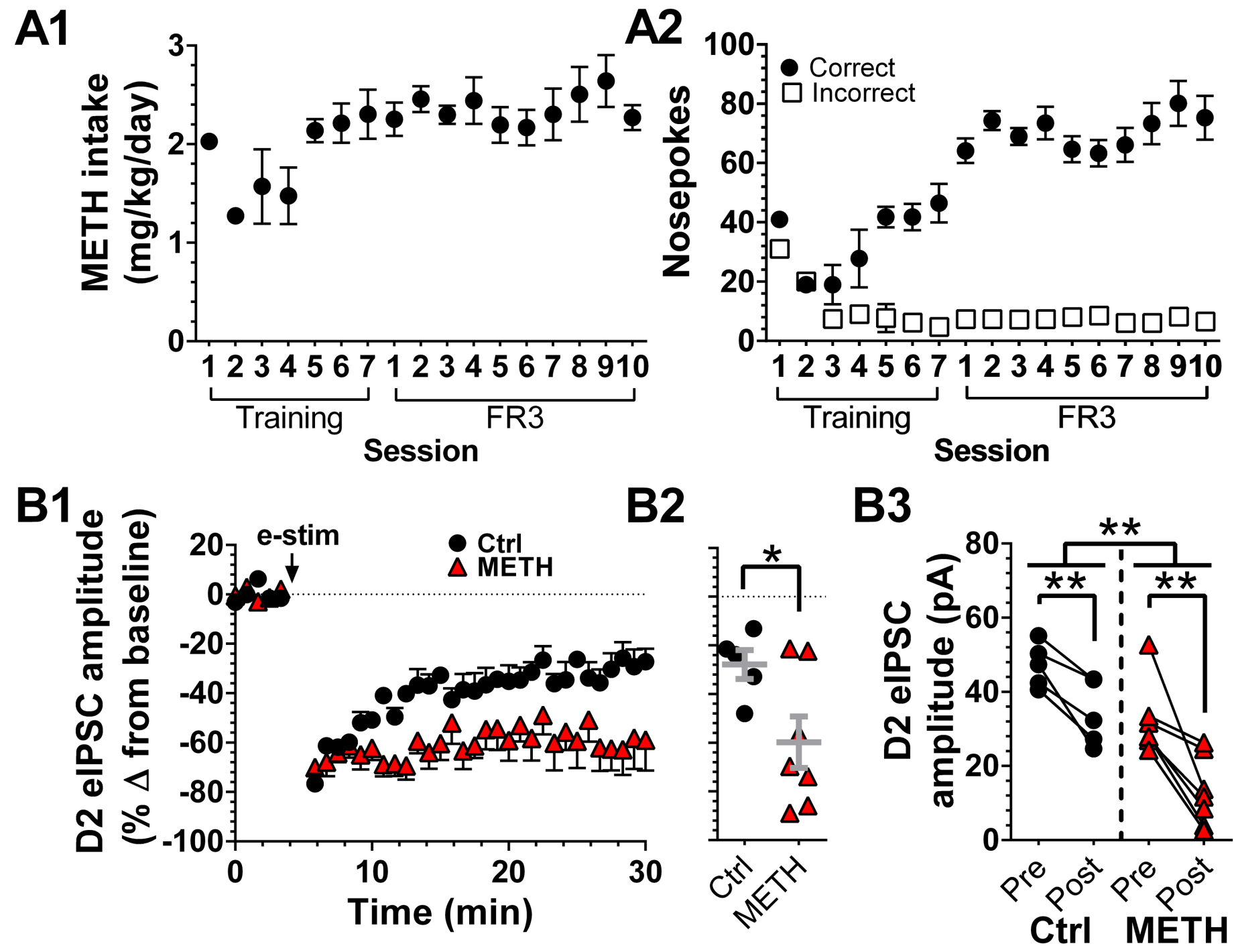
Figure S1. D2-LTD $\mathrm{DA}$ is not mediated by dopamine D1 receptors. Effect of dopamine-neuron specific stimulation (o-stim, $10 \mathrm{~Hz}$ blue light for $2 \mathrm{~min}$ ) on D2-oIPSCs recorded from SNc dopamine neurons in aCSF (control, grey circles, data first shown in Figure 1) or in the presence of the dopamine D1 receptor antagonist SKF 38393 (10 $\mu \mathrm{M}$, SKF, black squares), time-course (A) and raw amplitudes (B). Raw amplitudes are the average of 5 baseline sweeps (Pre) and the 5 sweeps 19-23 minutes following optostimulation (Post).
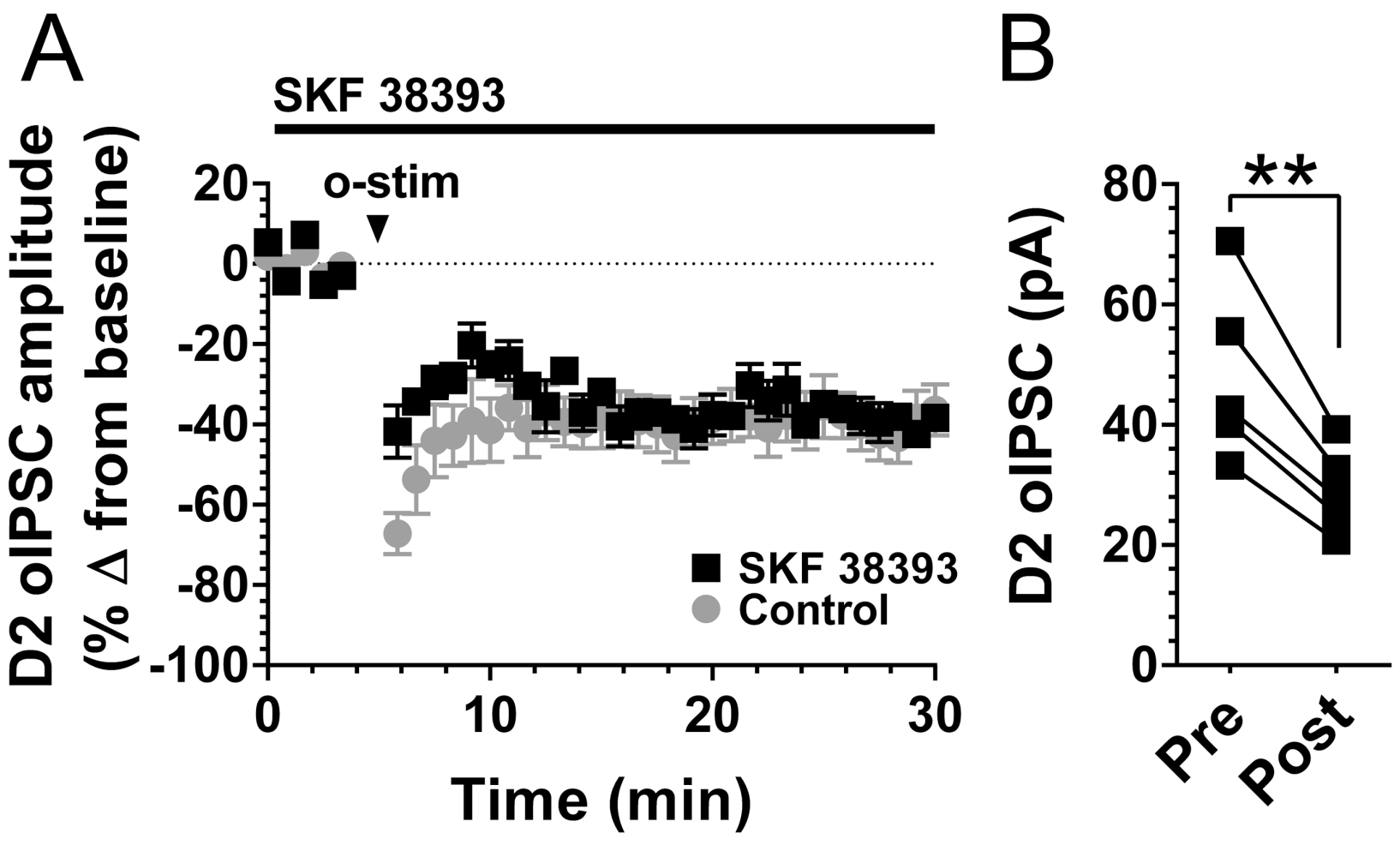
Figure S2. Repeated electrical stimulation drives LTD $_{D A}$ in the VTA. Effect of electrical stimulation (e-stim, $10 \mathrm{~Hz}$

stimulation through bipolar electrode for $2 \mathrm{~min}$ ) on D2-eIPSCs recorded from VTA dopamine neurons (A, B). All raw amplitudes are the average of 5 baseline sweeps (Pre) and the 5 sweeps 19-23 minutes following repeated stimulation (Post).

A

B
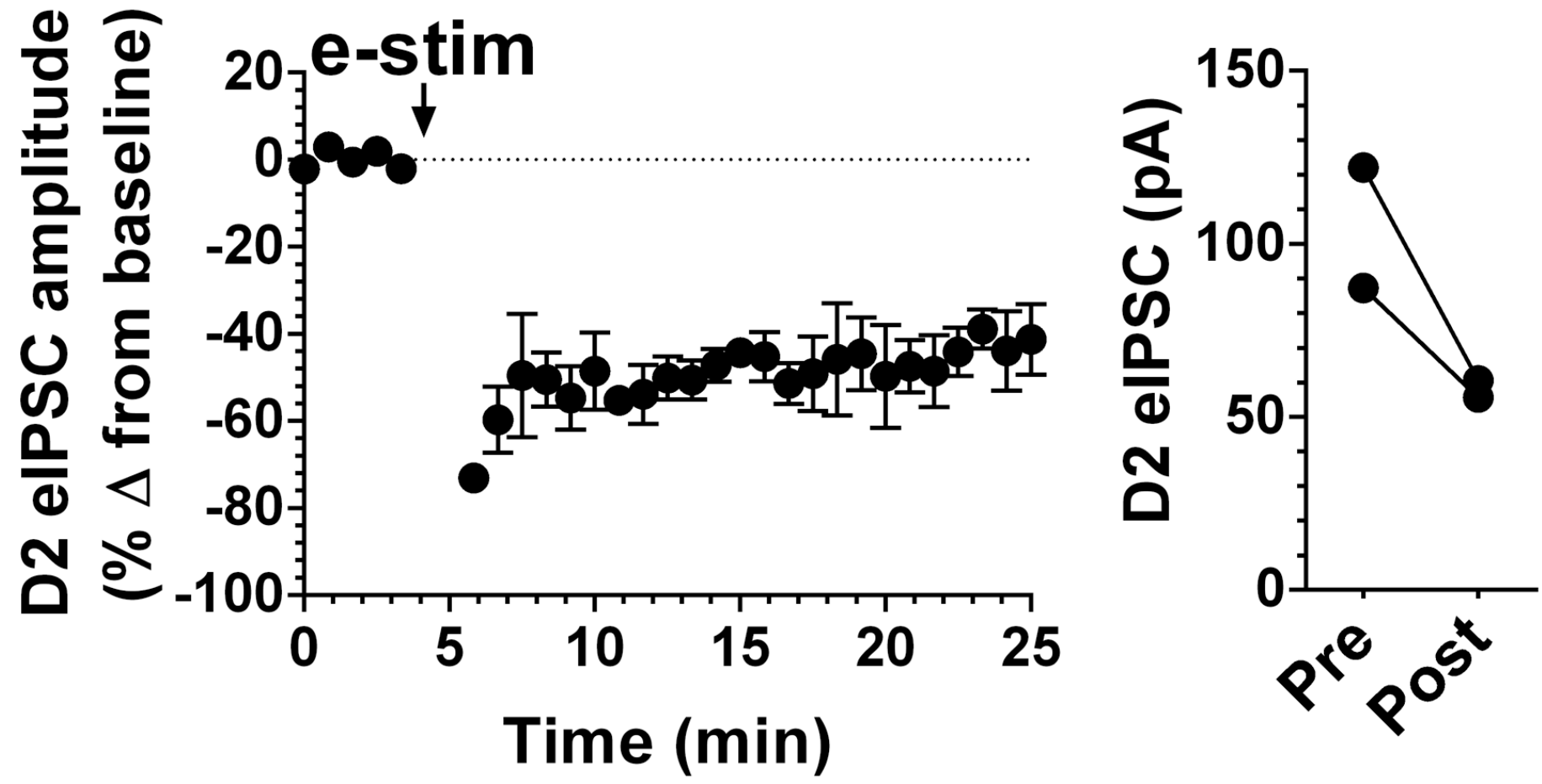


\section{References}

Bayer, V.E., Towle, A.C., Pickel, V.M., 1991. Ultrastructural localization of NT-like immunoreactivity within dense core vesicles in perikarya, but not terminals, colocalizing tyrosine hydroxylase in the rat ventral tegmental area. J. Comp. Neurol. 311, 179-196.

Beckstead, M.J., Grandy, D.K., Wickman, K., Williams, J.T., 2004. Vesicular dopamine release elicits an inhibitory postsynaptic current in midbrain dopamine neurons. Neuron 42, 939-946.

Beckstead, M.J., Williams, J.T., 2007. Long-term depression of a dopamine IPSC. J. Neurosci. 27, 2074-2080.

Bello, E.P., Mateo, Y., Gelman, D.M., Noaín, D., Shin, J.H., Low, M.J., Alvarez, V.A., Lovinger, D.M., Rubinstein, M., 2011. Cocaine supersensitivity and enhanced motivation for reward in mice lacking dopamine D2 autoreceptors. Nat. Neurosci. 14, 1033-1038.

Bellone, C. and Lüscher, C., 2006. Cocaine triggered AMPA receptor redistribution is reversed in vivo by mGluRdependent long-term depression. Nature neuroscience, 9, 636.

Betancur, C., Lépée-Lorgeoux, I., Cazillis, M., Accili, D., Fuchs, S., Rostène, W., 2001. NT gene expression and behavioral responses following administration of psychostimulants and antipsychotic drugs in dopamine $D(3)$ receptor deficient mice. Neuropsychopharmacology, 24, 170-182.

Bocklisch, C., Pascoli, V., Wong, J.C., House, D.R., Yvon, C., De Roo, M., Tan, K.R. and Lüscher, C., 2013. Cocaine disinhibits dopamine neurons by potentiation of GABA transmission in the ventral tegmental area. Science, 341, 15211525.

Brown, M.T., Bellone, C., Mameli, M., Labouèbe, G., Bocklisch, C., Balland, B., Dahan, L., Luján, R., Deisseroth, K. and Lüscher, C., 2010. Drug-driven AMPA receptor redistribution mimicked by selective dopamine neuron stimulation. PloS one, 5 , e15870.

Bose, P., Rompré, P.-P., Warren, R.A., 2015. NT enhances glutamatergic EPSCs in VTA neurons by acting on different NT receptors. Peptides 73, 43-50.

Castel M.N., Malgouris C., Blanchard J.C., Laduron P.M., 1990. Retrograde axonal transport of neurotensin in the dopaminergic nigrostriatal pathway in the rat. Neuroscience 36, 425-430.

Covey, D.P., Mateo, Y., Sulzer, D., Cheer, J.F. and Lovinger, D.M., 2017. Endocannabinoid modulation of dopamine neurotransmission. Neuropharmacology, 124, 52-61.

de Jong, J.W., Roelofs, T.J.M., Mol, F.M.U., Hillen, A.E.J., Meijboom, K.E., Luijendijk, M.C.M., van der Eerden, H.A.M., Garner, K.M., Vanderschuren, L.J.M.J., Adan, R.A.H., 2015. Reducing ventral tegmental dopamine d2 receptor expression selectively boosts incentive motivation. Neuropsychopharmacol. 40, 2085-2095. 
Dominguez-Lopez, S., Piccart, E., Lynch, W.B., Wollet, M.B., Sharpe, A.L., Beckstead, M.J., 2018. Antagonism of NT receptors in the ventral tegmental area decreases methamphetamine self-administration and methamphetamine seeking in mice. Int. J. Neuropsychopharmacol. 21, 361-370.

Dominguez-Lopez, S., Sharma, R., Beckstead, M.J., 2019. Neurotensin receptor 1 deletion decreases methamphetamine self-administration and the associated reduction in dopamine cell firing. bioRxiv [Pre-print] doi: 10.1101/697656.

Frankel, P.S., Hoonakker, A.J., Alburges, M.E., McDougall, J.W., McFadden, L.M., Fleckenstein, A.E., Hanson, G.R., 2011. Effect of methamphetamine self-administration on NT systems of the basal ganglia. J. Pharmacol. Exp. Ther. 336, 809815.

Gantz, S.C. and Bean, B.P., 2017. Cell-autonomous excitation of midbrain dopamine neurons by endocannabinoiddependent lipid signaling. Neuron 93, 1375-1387.

Gantz, S.C., Robinson, B.G., Buck, D.C., Bunzow, J.R., Neve, R.L., Williams, J.T. and Neve, K.A., 2015. Distinct regulation of dopamine D2S and D2L autoreceptor signaling by calcium. Elife, 4, e09358.

Geisler, S., Zahm, D.S., 2006. NT afferents of the ventral tegmental area in the rat: [1] re-examination of their origins and [2] responses to acute psychostimulant and antipsychotic drug administration. Eur. J. Neurosci. 24, 116-134.

Hanson, G.R., Hoonakker, A.J., Robson, C.M., McFadden, L.M., Frankel, P.S., Alburges, M.E., 2013. Response of NT Basal Ganglia Systems during Extinction of Methamphetamine Self-Administration in Rat. J. Pharmacol. Exp. Ther. 346, 173181.

Holroyd, K.B., Adrover, M.F., Fuino, R.L., Bock, R., Kaplan, A.R., Gremel, C.M., Rubinstein, M., Alvarez, V.A., 2015. Loss of feedback inhibition via D2 autoreceptors enhances acquisition of cocaine taking and reactivity to drug-paired cues. Neuropsychopharmacol. 40, 1495-1509.

Iversen, L.L., Iversen, S.D., Bloom, F., Douglas, C., Brown, M., Vale, W., 1978. Calcium-dependent release of somatostatin and NT from rat brain in vitro. Nature $273,161-163$.

Julian, M.D., Martin, A.B., Cuellar, B., De Fonseca, F.R., Navarro, M., Moratalla, R. and Garcia-Segura, L.M., 2003. Neuroanatomical relationship between type 1 cannabinoid receptors and dopaminergic systems in the rat basal ganglia. Neuroscience, 119, 309-318.

Kempadoo, K.A., Tourino, C., Cho, S.L., Magnani, F., Leinninger, G.-M., Stuber, G.D., Zhang, F., Myers, M.G., Deisseroth, K., de Lecea, L., Bonci, A., 2013. Hypothalamic NT projections promote reward by enhancing glutamate transmission in the VTA. J. Neurosci. 33, 7618-7626.

Kitabgi, P., De Nadai, F., Cuber, J.C., Dubuc, I., Nouel, D., Costentin, J., 1990. Calcium-dependent release of neuromedin $\mathrm{N}$ and NT from mouse hypothalamus. Neuropeptides 15, 111-114. 
Kortleven, C., Bruneau, L.C., Trudeau, L.E., 2012. NT inhibits glutamate-mediated synaptic inputs onto ventral tegmental area dopamine neurons through the release of the endocannabinoid 2-AG. Neuropharmacology 63, 983-991.

Krawczyk, M., Mason, X., DeBacker, J., Sharma, R., Normandeau, C.P., Hawken, E.R., Di Prospero, C., Chiang, C., Martinez, A., Jones, A.A., Doudnikoff, É., Caille, S., Bézard, E., Georges, F., Dumont, É.C., 2013. D1 dopamine receptormediated LTP at GABA synapses encodes motivation to self-administer cocaine in rats. J. Neurosci. 33, 11960-11971.

Laduron PM (1995) Functional consequences of retrograde axonal transport of receptor-bound neurotensin. Trends Pharmacol. Sci. 16, 338-343.

Leinninger, G.M., Opland, D.M., Jo, Y.H., Faouzi, M., Christensen, L., Cappellucci, L.A., Rhodes, C.J., Gnegy, M.E., Becker, J.B., Pothos, E.N. and Seasholtz, A.F., 2011. Leptin action via NT neurons controls orexin, the mesolimbic dopamine system and energy balance. Cell metab., 14, 313-323.

Liang, C.L., Sinton, C.M. and German, D.C., 1996. Midbrain dopaminergic neurons in the mouse: co-localization with Calbindin-D28K and calretinin. Neuroscience 75, 523-533.

Liu, Q.S., Pu, L. and Poo, M.M., 2005. Repeated cocaine exposure in vivo facilitates LTP induction in midbrain dopamine neurons. Nature, 437, 1027.

Mazella, J., Chabry, J., Kitabgi, P., Vincent, J.P., 1988. Solubilization and characterization of active NT receptors from mouse brain. J. Biol. Chem. 263, 144-149.

McCall, N.M., Kotecki, L., Dominguez-Lopez, S., Marron Fernandez de Velasco, E., Carlblom, N., Sharpe, A.L., Beckstead, M.J., Wickman, K., 2017. Selective ablation of GIRK channels in dopamine neurons alters behavioral effects of cocaine in mice. Neuropsychopharmacol. 42, 707-715.

Neuhoff, H., Neu, A., Liss, B. and Roeper, J., 2002. Ih channels contribute to the different functional properties of identified dopaminergic subpopulations in the midbrain. J. Neurosci. 22, 1290-1302.

Normandeau, C.P., Ventura-Silva, A.P., Hawken, E.R., Angelis, S., Sjaarda, C., Liu, X., Pêgo, J.M., Dumont, É.C., 2017. A key role for NT in chronic-stress-induced anxiety-like behavior in rats. Neuropsychopharmacol. 43, 285-293

O'Neill, B., Patel, J.C., Rice, M.E., 2017. Characterization of optically and electrically evoked dopamine release in striatal slices from digenic knock-in mice with DAT-driven expression of channelrhodopsin. ACS Chem. Neurosci. 8, 310-319.

Pan, P.Y. and Ryan, T.A., 2012. Calbindin controls release probability in ventral tegmental area dopamine neurons. Nature neuroscience, 15, 813-815.

Patterson, C.M., Wong, J.-M.T., Leinninger, G.M., Allison, M.B., Mabrouk, O.S., Kasper, C.L., Gonzalez, I.E., Mackenzie, A., Jones, J.C., Kennedy, R.T., Myers, M.G., 2015. Ventral tegmental area NT signaling links the lateral hypothalamus to locomotor activity and striatal dopamine efflux in male mice. Endocrinology 156, 1692-1700. 
Paxinos, G. and Franklin, K.B., 2004. The mouse brain in stereotaxic coordinates. Gulf professional publishing.

Piccart, E., Courtney, N.A., Branch, S.Y., Ford, C.P., Beckstead, M.J., 2015. NT induces presynaptic depression of d2 dopamine autoreceptor-mediated neurotransmission in midbrain dopaminergic neurons. J. Neurosci. 35, 11144-11152.

Regehr, W.G., Carey, M.R. and Best, A.R., 2009. Activity-dependent regulation of synapses by retrograde messengers. Neuron 63, 154-170.

Robinson, B.G., Bunzow, J.R., Grimm, J.B., Lavis, L.D., Dudman, J.T., Brown, J., Neve, K.A., Williams, J.T., 2017.

Desensitized D2 autoreceptors are resistant to trafficking. Sci. Rep. 7, 4379.

Rogers, J.H., 1992. Immunohistochemical markers in rat brain: colocalization of calretinin and calbindin-D28k with tyrosine hydroxylase. Brain res. 587, 203-210.

Saal, D., Dong, Y., Bonci, A. and Malenka, R.C., 2003. Drugs of abuse and stress trigger a common synaptic adaptation in dopamine neurons. Neuron, 37, 577-582.

Sarret, P., Beaudet, A., Vincent, J.-P., Mazella, J., 1998. Regional and cellular distribution of low affinity NT receptor mRNA in adult and developing mouse brain. J. Comp. Neurol. 394, 344-356.

Schultz, W., 1998. Predictive reward signal of dopamine neurons. J. Neurophysiol., 80, 1-27.

Seroogy, K., Ceccatelli, S., Schalling, M., Ho, T., Frey, P., Walsh, J., Dockray, G., Brown, J., Buchan, A. and Goldstein, M., 1988. A subpopulation of dopaminergic neurons in rat ventral mesencephalon contains both neurotensin and cholecystokinin. Brain Res., 455, 88-98.

Sharpe, A.L., Varela, E., Bettinger, L., Beckstead, M.J., 2014. Methamphetamine self-administration in mice decreases GIRK channel-mediated currents in midbrain dopamine neurons. Int. J. Neuropsychopharmacol. 18, pii: pyu073.

Stiller, C.-O., Gustafsson, H., Fried, K., Brodin, E., 1997. Opioid-induced release of NT in the periaqueductal gray matter of freely moving rats. Brain Res. 774, 149-158.

Stuhrman, K., Roseberry, A.G., 2015. NT inhibits both dopamine- and GABA-mediated inhibition of ventral tegmental area dopamine neurons. J. Neurophysiol. 114, 1734-1745.

Tanaka, K., Masu, M., Nakanishi, S., 1990. Structure and functional expression of the cloned rat NT receptor. Neuron 4, 847-854.

Taupenot, L., Harper, K.L., O’Connor, D.T., 2005. Role of H+-ATPase-mediated acidification in sorting and release of the regulated secretory protein chromogranin a evidence for a vesiculogenic function. J. Biol. Chem. 280, 3885-3897.

Tschumi, C.W., Beckstead, M.J., 2018. NT speeds inhibition of dopamine neurons through temporal modulation of GABAA and GABAB receptor-mediated synaptic input. Neuropharmacology 131, 414-423. 
bioRxiv preprint doi: https://doi.org/10.1101/717843; this version posted August 28, 2019. The copyright holder for this preprint (which was not certified by peer review) is the author/funder, who has granted bioRxiv a license to display the preprint in perpetuity. It is made available under aCC-BY-NC-ND 4.0 International license.

Tschumi, C.W., Beckstead, M.J., 2019. Diverse actions of the modulatory peptide NT on central synaptic transmission. Eur. J. Neurosci. 49,784-793.

Ungless, M.A., Whistler, J.L., Malenka, R.C. and Bonci, A., 2001. Single cocaine exposure in vivo induces long-term potentiation in dopamine neurons. Nature, 411, 583.

Wolfart, J., Neuhoff, H., Franz, O. and Roeper, J., 2001. Differential expression of the small-conductance, calciumactivated potassium channel SK3 is critical for pacemaker control in dopaminergic midbrain neurons. J. Neurosci. 21, 3443-3456.

Zweifel, L.S., Parker, J.G., Lobb, C.J., Rainwater, A., Wall, V.Z., Fadok, J.P., Darvas, M., Kim, M.J., Mizumori, S.J., Paladini, C.A. and Phillips, P.E., 2009. Disruption of NMDAR-dependent burst firing by dopamine neurons provides selective assessment of phasic dopamine-dependent behavior. Proc. Natl. Acad. Sci. U.S.A., 106, 7281-7288. 


\section{Materials and Methods}

\section{Animals}

Male and female mice (6 - 52 weeks) were used for all experiments. Genetic lines were obtained from Jackson Labs (C57BI/6J, DAT-Cre, and Cre-ChR2, Bar Harbor, ME) except for NTS-Cre mice which were generously provided by Dr. Gina Leinninger (Leinninger et al., 2011). Mice were group-housed when littermates were available in polycarbonate chambers with rodent bedding. The vivarium was on a reverse 12/12 light cycle (lights off at 0900). Animal usage was reviewed and approved by Institutional Animal Care and Use Committees at the University of Texas Health Science Center at San Antonio and the Oklahoma Medical Research Foundation.

\section{Mouse genotyping}

DNA was extracted from mouse ear punches using Extract-N-Amp ${ }^{\circledR}$ (Sigma, St. Louis, MO) per the manufacturer's instructions and used for PCR amplification. Genotyping was performed either on the University of Texas Health Science Center at San Antonio campus using the protocols listed below or performed by Transnetyx (Cordova, TN) using realtime PCR.

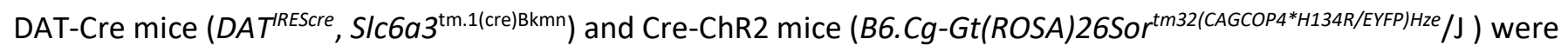
genotyped using a multiplex PCR reaction as per the outlined protocols (https://www2.jax.org/protocolsdb/f?p=116:5:0::NO:5:P5_MASTER_PROTOCOL_ID,P5_JRS_CODE:23107,006660) and (https://www2.jax.org/protocolsdb/f?p=116:5:0::NO:5:P5_MASTER_PROTOCOL_ID,P5_JRS_CODE:28710,024109),

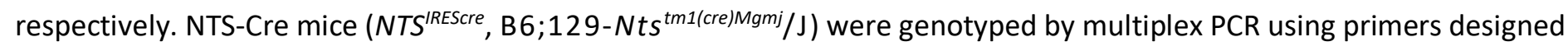
by Dr. Richard Palmiter, University of Washington: 5'CAATGGTGCGCCTGCTGGAAG3',

5'CATGAATGCAAGAAACATCACATCC3' and 5'TCCAGGAAGATATCCTTGATAACG3'.

\section{Stereotaxic surgery and vector delivery}

Stereotaxic surgeries were conducted using a stereotaxic instrument (Kopf Instruments, Tujunga, CA). Mice were anesthetized with isoflurane kept steady at 1.5-2\% using a Somnosuite low-flow anesthesia system (Kent Scientific, Torrington, CT). Access holes were drilled bilaterally in the skull and 33-gauge stainless steel injectors were lowered to one set of the following coordinates in mm: SNc; M/L: 1.25, A/P: -4.7, D/V: -4.7; LH; M/L: 0.9, A/P: -1.1, D/V: -5.25; NAc; M/L: 2.44, A/P: 1.65, D/V: -4.35 @ 20 degrees. At least 3 weeks before electrophysiological experiments, mice were injected with $400 \mathrm{nl}$ of cre-inducible viral vector AAV5-EF1a-DIO-hChR2(H134R)-EYFP-WPRE-pA (University of North Carolina Vector Core, Chapel Hill, NC) synthesized in the lab of Dr. Karl Deisseroth, and mice received injections of $20 \mathrm{mg} / \mathrm{ml}$ ticarcillin (antibiotic; Sigma-Aldrich) and $0.8 \mathrm{mg} / \mathrm{ml}$ ketoprofen (analgesic; Hospira, Lake Forest, IL) postsurgery. 


\section{Catheter implantation surgery}

Catheters were constructed in-house using micro-renathane tubing (0.025" o.d., 0.012" i.d; Braintree Scientific, Braintree, MA) with one end attached to a piece of 26-gauge hypodermic tubing (Component Supply, Sparta, TN) bent at a 90-degree angle. The other end of the hypodermic tubing was threaded through the center of a nylon screw. An oval of polyester felt mesh was secured around the base of the screw using silicone medical adhesive (Factor II, Lakeside, AZ). Adhesive was also used to secure hypodermic tubing to the nylon screw with an additional adhesive bead applied approximately $10 \mathrm{~mm}$ from the unattached end of the micro-renathane tubing to help anchor the catheter during surgery. Aseptic surgeries were performed as described previously (Sharpe et al. 2014). Mice were anesthetized with 2$3 \%$ isoflurane using a Somnosuite low-flow anesthesia system. Catheters were placed within a dorsal incision site with the nylon screw perpendicular to the spine. Felt mesh was secured subcutaneously around the dorsal incision while the micro-renathane tubing was threaded subcutaneously to the ventral side. Tubing was inserted into the right jugular vein via ventral incision and anchored using surgical silk sutures (Surgical Specialties, Wyomissing, PA) just below the adhesive bead. Blood was aspirated through the catheter to ensure successful placement. Incision sites were secured with stainless steel wound clips (CellPoint Scientific, Gaithersburg, MD) and the open top of the hypodermic tube was covered by a short piece of heat fused PE20 tubing (Instech Laboratories, Plymouth Meeting, PA) to prevent infection and clotting. Mice received injections of ticarcillin and ketoprofen for pain alleviation and infection prevention postsurgery. Mice were allowed to rest at least 6 days after surgery before beginning daily operant self-administration sessions. Catheters were flushed with heparinized saline (0.2-0.3 ml) (30units/mL; Sagent Pharmaceuticals, Schaumburg, IL) prior to operant sessions.

\section{Operant self-administration of methamphetamine}

Operant sessions were conducted inside modular mouse operant chambers (Lafayette Instruments, Lafayette, IN) with two nose-poke holes on one wall. One hole per chamber was designated as the "correct" nose-poke hole, with nosepokes resulting in delivery of methamphetamine through surgically implanted jugular catheters. The second nose-poke hole was designated as "incorrect", and nose-pokes into this hole had no programmed consequences. Daily 2-hour operant sessions were performed as previously described (Dominguez-Lopez et al. 2018). During training mice progressed within-session from a fixed-ratio 1 (FR1) schedule of reinforcement (one nose-poke in the active hole resulting in one infusion of methamphetamine) to a FR3 response requirement. Meeting the response requirement resulted in a $0.1 \mathrm{mg} / \mathrm{kg} / \mathrm{inf}$ dose of METH (a volume of $12 \mu \mathrm{l}$ over 2 seconds assuming a $28 \mathrm{~g}$ adult mouse) directly into their jugular vein. This occurred simultaneously with both a $2 \mathrm{kHz}$ sound cue and illumination of a white-light cue in the chamber's food receptacle and was followed by a 15 second timeout period during which nose-pokes in either hole had no programmed consequences. Acquisition of self-administration was defined as self-administering at least 8 infusions of METH with at least $70 \%$ of responses being made in the correct side nose-poke hole for 2 consecutive sessions. After 
acquisition, the response requirement to receive one METH infusion was fixed at FR3 and operant sessions continued for a minimum of 9 daily 2-hour sessions followed by 1-3 days in the home cage before ex vivo electrophysiological recordings.

\section{Brain slice electrophysiology}

On the day of the experiment, mice were anesthetized with isoflurane and immediately decapitated. Brains were extracted and placed in ice-cold carboxygenated $\left(95 \% \mathrm{O}_{2}, 5 \% \mathrm{CO}_{2}\right)$ artificial cerebral spinal fluid (aCSF) containing the following (in mM): $126 \mathrm{NaCl}, 2.5 \mathrm{KCl}, 1.2 \mathrm{MgCl}_{2}, 2.4 \mathrm{CaCl}_{2}, 1.4 \mathrm{NaH}_{2} \mathrm{PO}_{4}, 25 \mathrm{NaHCO}_{3}$, and $11 \mathrm{D}$-glucose. For $\mathrm{Ca}^{2+}$ free experiments $\mathrm{CaCl}_{2}$ was replaced with $\mathrm{MgCl}_{2}$ (for a total of $3.7 \mathrm{mM}$ ) and $0.5 \mathrm{mM} \mathrm{EGTA}$. Kynurenic acid (1 mM) was added to the buffer for the slicing procedure. Horizontal midbrain slices $(200 \mu \mathrm{m})$ containing the SNc and VTA were obtained using a vibrating microtome (Leica, Wetzlar, Germany). Slices were incubated for at least $30 \mathrm{~min}$ at $34-36^{\circ} \mathrm{C}$ with carboxygenated aCSF that also contained the NMDA receptor antagonist MK-801 (10-20 $\mu \mathrm{M})$ unless noted otherwise.

Slices were placed in a recording chamber attached to an upright microscope (Nikon Instruments, Tokyo) and maintained at $34-36^{\circ} \mathrm{C}$ with aCSF perfused at a rate of $1.5 \mathrm{ml} / \mathrm{min}$. Dopamine neurons were visually identified using gradient contrast optics based on their location in relation to the midline, medial lemniscus, and the medial terminal nucleus of the accessory optic tract. Neurons were further identified physiologically by the presence of spontaneous pacemaker firing $(1-5 \mathrm{~Hz})$ with wide extracellular waveforms $(>1.1 \mathrm{~ms})$ and a hyperpolarization-activated current $\left(\mathrm{I}_{\mathrm{H}}\right)$ of $>100$ pA. Recording pipettes (1.5-2.5 M $\Omega$ resistance) were constructed from thin wall capillaries (World Precision Instruments) with a PC-10 puller (Narishige International). Whole-cell recordings were obtained using an intracellular solution containing the following (in $\mathrm{mM}$ ): $115 \mathrm{~K}$-methylsulfate, $20 \mathrm{NaCl}, 1.5 \mathrm{MgCl}_{2}, 10 \mathrm{HEPES}, 2 \mathrm{ATP}, 0.4 \mathrm{GTP}$, and either 10 BAPTA or 0.025 EGTA, pH 7.35-7.40, 269-274 mOsm.

D2-IPSCs were evoked during voltage-clamp recordings (holding voltage, $-55 \mathrm{mV}$ ) using electrical stimulation (D2-elPSCs, 5 stimulations of $0.5 \mathrm{~ms}$ applied at $50 \mathrm{~Hz}$ ) delivered by bipolar stimulating electrode that was inserted into the slice 100$200 \mu \mathrm{m}$ caudal to the patched cell in the presence of the following receptor antagonists: picrotoxin (100 $\left.\mu \mathrm{M}, \mathrm{GAB} \mathrm{A}_{A}\right)$,

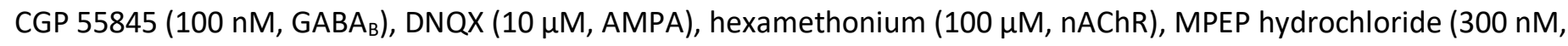
mGluR5), and JNJ 16259685 (500 nM, mGluR1). D2-IPSCs were also evoked via blue light (D2-olPSCs) with 4 stimulations of $5 \mathrm{~ms}$ applied at $50 \mathrm{~Hz}$ generated either by laser (Optoengine, $100 \mathrm{~mW}$ max power, $473 \mathrm{~nm}$ ) and delivered through a fiber optic cable (200 $\mu \mathrm{m}$ core, 0.39 NA, Thorlabs), the tip of which was placed 100-200 $\mu \mathrm{m}$ caudal to the patched cell, or generated by high-power LED (Solis-3C, 20mW max power, Thorlabs) and delivered through the microscope objective after passing through a filter cube (TLV-TE2000, Thorlabs). Both D2-eIPSCs and D2-oIPSCs were evoked once-every 50 seconds. D2-oIPSCs shown in Figure 2 panels D1-2 were recorded in DAT-Cre mice in which ChR2 was expressed by AAV delivered into the SNc (see previous section). For antagonist and inhibition experiments, compounds were either included in the recording pipette and allowed to dialyze for 10 minutes after breaking into the cell, or bath perfused for at least 10 minutes immediately before repeated stimulation and continued throughout the length of the recording. 


\section{Fluorescent labeling and imaging}

Brain samples were embedded in OCT cryo-matrix with the coronal fissure oriented to the bottom of the mold. Enough OCT was added to the mold to cover the sample halfway leaving approximately $50 \%$ of the sample exposed. The brains were sectioned coronally on a Leica CM3050 cryostat at $40 \mu \mathrm{m}$. Each sample was collected at 3 different areas of interest (Franklin and Paxinos, 2008; NAc [1.98 to $0.74 \mathrm{~mm}]$, LH [-0.58 to $-2.54 \mathrm{~mm}$ ], VTA [-2.54 to $-3.80 \mathrm{~mm}]$ ). Sections were transferred to a well plate containing a 1X phosphate buffered saline (PBS). Once completed the well plates were sealed with parafilm and stored at $4^{\circ} \mathrm{C}$.

Sections were blocked at room temperature for 1 hour with $5 \%$ normal donkey serum (Abcam ab7475). Sections were washed in PBS $+0.1 \%$ TWEEN-20 then incubated with primary antibodies $+2 \%$ normal donkey serum for 22 hours at $4{ }^{\circ} \mathrm{C}$. Sections were then washed in PBS and incubated with secondary antibodies for 2 hours at room temperature. After final washes in PBS, sections were mounted on gelatin-coated slides and cover slips were applied using Prolong Diamond anti-fade reagent (Thermo Fisher Scientific). Primary antibodies used were goat anti-GFP (1:500; Novus NB100-1770) for eYFP, and chicken anti-tyrosine-hydroxylase (1:1000; Abcam ab76442). Secondary antibodies used were donkey antigoat Alexa Fluor 488 (1:750; Jackson ImmunoResearch 705-545-147), and donkey anti-chicken Rhodamine Red-X (1:200; Jackson ImmunoResearch 703-295-155). Primary and secondary antibodies were incubated with PBS + 0.3\% triton-x.

Sections were imaged using a Zeiss LSM 710 confocal microscope with a 40x objective. ZEN Microscope Software (Carl Zeiss Microscopy, Thornwood, NY) was used for image acquisition. Final images were obtained at single planes or through maximum intensity flattened z-stacks ( $1 \mu \mathrm{m}$ between planes) generated using Image (National Institutes of Health, Bethesda, MD).

\section{Pharmacological agents}

Methamphetamine hydrochloride was a generous gift from the National Institute on Drug Abuse drug supply program (Bethesda, MD). Kynurenic acid, MK-801, DNQX, picrotoxin, dopamine, sulpiride, hexamethonium, SKF38393, concanamycin A, tetrodotoxin, and SR142948 were purchased from Sigma-Aldrich. SR48692, CGP55845, JNJ 16259685, and MPEP hydrochloride were purchased from Tocris Bioscience. The active fragment $\mathrm{NT}_{8-13}$ was purchased from American Peptide Company.

\section{Experimental design and statistical analyses}

Data were collected on a Dell computer running Windows 7 using Axograph version 1.5.4 and LabChart (AD Instruments). Statistical analyses were performed using Prism Graphpad version 6. In most cases the effect of repetitive stimulation was analyzed using an average of the 5 sweeps immediately preceding stimulation (sweeps $1-5$, pre) and 
bioRxiv preprint doi: https://doi.org/10.1101/717843; this version posted August 28, 2019. The copyright holder for this preprint (which was not certified by peer review) is the author/funder, who has granted bioRxiv a license to display the preprint in perpetuity. It is made available under aCC-BY-NC-ND 4.0 International license.

sweeps 31-35 (post). In rare cases where less than 5 sweeps were available, the sweeps within that range (at least 2) were averaged for analysis. Tukey's post hoc tests were performed subsequent to significant ANOVAs. Data are presented as mean \pm SEM. In all cases, $\alpha$ was set a priori at 0.05 . 